\title{
Silent Innovations in Federal Civil Service. Argentina 1989-1999 \\ Dora Orlansky*
}

This paper discusses the three phases of the State Reform process during President Menem's two terms of office (1989-1995; 1995-1999). The first phase involved the greatest changes: the privatization of state-owned companies, the decentralization and transfer, to provincial governments, of the government's main social functions (education, health, housing, social welfare, etc.) and a reorganization, though a "politicized" one, of the national government's agencies and the civil service. The second phase - also called the "second" State Reform focused on an ambitious modernization of the government establishment, but did not meet its objectives. Finally, when the decade of Menem's administration was about to end, the government undertook the last and much postponed changes in the civil service working conditions. This paper will focus on these two final years.

\section{9: The State Reform - first phase}

By the end of the Radical Party administration (1983-1989), fiscal adjustment was considered essential in the light of the State's financial imbalances. In April 1989, the repeated inflation acceleration processes in the domestic economy clearly showed the need to overcome the chronic fiscal imbalance. Both in the economic and political arenas, opinion was widespread that the fiscal deficit was the main cause of runaway inflation rates. The Alfonsín administration then decided that a public sector reform intended to reduce imbalances was inevitably necessary to build economic stability. Aside from promoting a political agreement with the coming administration for the following presidential term, the government set the following points in its economic program: a) fiscal deficit reduction down to a minimum compatible with external financing, b) improvement of tax returns, c) public spending restrictions and d) increase - in real terms in public fares up to a point where the financing of capital investment in stateowned companies could be assured.

\footnotetext{
* Director of Research and Professor, Instituto de Investigaciones Gino Germani and Department of Political Science, Faculty of Social Sciences, University of Buenos Aires, Argentina.

An early version of this paper was prepared for presentation at the IPSA, International Political Science Association, XVII World Congress, Quebec City, Canada, 1-6 August 2000, with the collaboration of Diana Gomez, Silvana Kostenbaum and Myriam Orciani.
} 
The desperate fiscal situation and the need to implement adjustment policies and stability plans were thus dramatically revealed in the midst of the 1989 presidential elections and exacerbated during the critical times of the transition from the radical to the Justicialist government. In this context and on the verge of ingovernability, when the Menem administration was just beginning, the State Reform Act and Economic Emergency Act were passed ${ }^{1}$. These were bills proposed by the Executive Branch in an unprecedented political agreement whereby the Radical Party - the largest opposition party - gave its vote of support in Congress. Based on these two sole legal instruments that passed through Congress, a "new administrative order" was opened and structurally redefined the public sector ${ }^{2}$.

In consonance with the "Washington Consensus" ${ }^{3}$, the State Reform process during the Menem administration mainly involved the privatization of state-owned companies, the deregulation of markets and the decentralization of various functions to be distributed among sub-national jurisdictions [Gerchunoff and Cánovas, 1995; Orlansky, 1989, 1991, 1994, 2000; Oszlak, 1999]. One of the last instruments of this period was Executive Order 992 on the National System for the Civil Service Profession (SINAPA) which set forth in 1991 a promotion system for the National Public Administration personnel aimed at organizing and systematizing the administrative career.

The disappearance of the entrepreneurial state and the resulting reduction of public employment was one of the outstanding features of the first-phase reforms. The need to collect liquid funds to pay the debts resulted in the prioritization to transfer public utility companies, which, in some cases, were monopolies per se. Owing to the preeminence of macroeconomic objectives, most of these operations were made at once and in hardly a gradual manner, and regulatory master agreements were prepared or changed after the transfers were made [Gerchunoff, Cánovas, 1995]. As regards the decentralization process, we can only highlight the transfer of responsibilities from the Federal government to the provinces, leading to payroll increase in the areas transferred, education, health, social welfare, etc., to sub-national jurisdictions.

While the number of employees in the Federal public sector $(1,100,000)$ dropped genuinely as a result of state owned companies privatization's $(300,000$ jobs) - and through social functions transferred (340,000 jobs) towards subnational administrative levels' payrolls (estimated in 100,000 jobs, before decentralization) the volume of employees in political areas rose not only in relative but also in absolute numbers. In other words, the number of positions in the more political jurisdictions of the Federal government and in the top cabinet positions grew.

\footnotetext{
1 Acts 23696 and 23697, respectively.

2 State reform policies were formulated in a " cascade » manner. In 1989, they consisted in a consolidated package of two acts (Nrs. 23696, and 23697) and, later, in a series of « necessity and urgency »-motivated executive orders. In 1990, Executive Order 435 of State Reorganization; Executive Order 1457 called «Omnibus » to accelerate the State Reform and Executive Order 2476 of State Rationalization, main provisions relating to the personnel status. In 1991, Executive Order 992 on the National Civil Service Profession System (SINAPA).

3 It set forth a set of measures for attaining economic stability such as privatizations, economic liberalization, fiscal discipline, etc.
} 
Through voluntary retirements, redundancies, separations, compulsory retirements and the implementation of a new personnel promotion system, an intense turnover took place in the Federal civil service, that emphasized the political profile, at the expense of civil servants' autonomy and clear cut limits between government and party politics [Orlansky, 1991, 1994].

The political uplift was, on the one hand, an automatic result of the reorganization that started in 1989. Once the state-owned companies were privatized and the social role was decentralized under the argument of fiscal federalization, the number of public employees in the Federal government decreased. At the same time, payrolls in political functions increased and not only in relative terms. In absolute terms, the number of positions in the more political sectors of government (President's office, Ministry of the Interior [Orlansky, 1994], Ministry of Economy and the most recently created Chief of Staff's office) grew.

But the state's over sizing - at the political leadership level - was not only apparent in the numbers. The civil service has been "politicized" in a different sense: since 1990, organizations and government agencies multiplied exponentially (Secretariats, Under-secretariats, Directorates). Also, political turnover at government management level allowed a political clientele control and a corporative control over labor, by the Union of National Civil Servants (UPCN), a pro-Menem Government union, which became involved in areas such as employee recruitment, re-categorization and promotion (Executive Order 992/91, "SINAPA"). Membership of UPCN was - though not explicitly - a condition to recruitment. As tautological as a statement regarding the "politicizing" of the State $^{4}$ may sound, the way in which ruling party politics - i.e., the confrontation between its different sectors and the conflict of general and particular interests ${ }^{5}$ spilt over the boundaries of government was unprecedented. This resulted in some periods of division of areas of influence and in the creation of inter-bureaucratic, particularistic networks with a hegemonic concentration of personal power; this was the case of Mr. Cavallo, Economy Minister (1991-1996), and his involvement in the appointment of officials for agencies outside his incumbency.

Despite the official antistatic rhetoric's, the size of federal executive branch departments was blown up. Restrictive acts, bills and executive orders concerning State Reform were in fact distorted. There had been many dismissals; but new employees were hired at the same time and some even re-hired again. In the office of the Presidency many employees under their retirement pension plan (the socalled "privileged pension" on account of the many benefit granted) returned to their posts by ways of contracts. Personnel reducing structures were approved, many agencies eliminated (often only in papers), voluntary resignation with substantial compensations as well as anticipated or compulsory retirement were applied and dismissals executed. But all this bunch of policies were reverted by

4 The description of «political inflation » (mechanisms of clientele attraction, expansion of organizations and senior administration positions held for political loyalties, etc.) [Orlansky, 1994].

5 For instance, a program ( Nueva Dirigencia ») promoting « young leadership » among members of the official party, Partido Justicialista, had been carried out from inside a governmental agency. Afterwards it was a faction converted in a new political party itself. 
means of several executive orders ruling a lot of "exemptions". By the end of 1992, there were 98 undersecretaries in the area of the federal executive branch, even though Executive Order 435/1990 has established a maximum of 32. A year later the figure climbed to 140 . The top level appointees profusely multiplied; the number of advisors increased ( 92 for a former Minister of the Interior); tenure public employment augmented. So, the top structure of government and the volume of public employment have been enlarged by means of a peculiar political alchemy of "exits and entries". Thousands of positions and employees had been eliminated at high cost while being simply replaced by others, and even many more than before; a sort of relentless clientelistic circulation.

The previous public administration labor law was replaced by the National System for Administrative Profession, known as "SINAPA" and salaries, promotion, positions, levels, categories, etc. were redefined. As a matter of fact, the conversion from the previous hierarchical listing of 24 categories to the new one of 6 implied the redefinition of levels, categories and salaries for all the personnel. The results of equivalencies were not satisfactory for a greater part of employees. Conflicts begun and the influential officialist civil servants union UPCN $^{6}$ was informally consulted, and its member benefited from the process of reclassification. Another important source of patronage discretion was the design and results of the so-called " compassion for the executive positions » in the public bureaucracy. Extensively advertised "open selection" concealed the fact that qualification consisted of a ranking where the highest position was filled by three names presents as candidates, among which the political authority made a decision. There has been practically no remotion; a parti pris favoring those who had been appointed by same authorities prior to selection. Both "replacements" of categories into the new labor framework and "competitions" 7 for executive positions have concealed subtle maneuvers of political manipulation; these legal devices improved the former ones like voluntary resignment, compulsive retirement, etc. The role of unions has been included in the SINAPA; only the officialist UPGN was allowed to send an « inspector» (to see but not to vote) when decisions about recruitment's or promotion are taken. Nevertheless, the powerful union was currently able to accomplish an informal particularistic influence. Conversely, the other mayor public employees union, ATE ${ }^{8}$, that did not agree with the "pro Menem syndicalism" was excluded.

6 UPCN was recreated in 1948, as the follower or the former "Liga de Empleados Públicos », the union born in 1930 supporting the General Uriburu «nationalistic » military coup. It historically appeals to the very " white collar ", i.e. the high level functionaries, usually more " officialists " and ideologically " wrightists ". In the present days UPCN is proud to make know that the IDB (International Development Bank) appointed the UP (Unión Personal, UPCN's welfare organization) as one of the best organized and ruleabiding institutions of its kind.

7 The expression « competition » - a mere euphemism - was later replaced by a less controversial and pretentious term as «selection »; a semantic exchange that eliminates the possibility of legal contestation of irregularities.

8 ATE was created in 1925 inspired in a socialist orientation. From its beginnings it included the "blue collar» workers in the public infrastructure (ports, roads, etc.) and administrative employees of the low levels. Also the personnel from the military factories institution (Fabricaciones Militares) were members of ATE; unlike public utility companies passed to the private sector, these factories were mostly wound-up due to lack of buyers. 
Another striking feature of labor policy consists of a strong salaries polarization. Salaries' dispersion was magnified even though an increase of around $20 \%$ of the salary mass was forecasted from the new administrative system implementation. Moreover, salary freezing was applied, except at the highest levels where salaries were permanent and substantially raised. The insistence to make salaries increases depending on a fuzzy concept of productivity imposed budget restraints that did not allow to offer better compensations but extremely selective increases to those who had greater responsibilities. In 1993 the "critical positions with executive functions" had a salary level of around 4,900 Argentine Pesos (or US Dollars), 20 times the salary of the lowest position, and more than twice the salary of same position before 1991.

However, there is not guarantee that holders of critical executive positions will maintain their positions or remaining in their executive functions because of the permanent mutations of national government. A change of minister in the Menem Administration currently implied not only a replacement of the political appointees but a new administrative reorganization; consequently, the administrative reform of a former minister was mostly neglected.

\section{6: Second State Reform}

In February 1996, the State Reform issue was once again brought to the surface, now called the "Second Reform", through Act 24629 which, in its second chapter, discusses the administrative reorganization of the state, emphasizing the need to improve the operation and quality of services rendered by Federal government agencies, as well as their financing. To that end, it provided for a national public sector reorganization to attain more efficiency and rationalization. The proposals were as follows: 1) Change, merger or transfer of government agencies to the provinces, following their prior agreement, 2) total or partial elimination of overlapping or duplicate objectives, competencies, functions and responsibilities, or of such agencies that had become manifestly unnecessary, 3) reorganization or total or partial elimination of decentralized agencies created by law, 4) privatization of activities related to the provision of supplemental services and works or goods production under the management of the central government jurisdictions or agencies - provided that this would not imply affecting essential services in which higher efficiency, as well as better service levels to the users or the community would have to be achieved, with a reduction in costs or a better public resource allocation to those ends. The enforcement authority for this Act was the Presidential Chief of Staff (called Ministers Cabinet Chief), who was empowered to enforce the fulfillment of the objectives set forth in the abovementioned Act as well as to consider any exceptions ${ }^{9}$.

Likewise, the same Act 24629 provided for the creation of a Labor Reorientation Training Fund (Fondo de Reconversión Laboral) for the National

9 The presidential chief of staff's position (Cabinet Chief) was created under the 1994 Constitutional Reform. Among other things, it is in charge of the organization and administrative personnel of the executive branch. 
Public Sector, the purpose of which was to train and provide technical assistance to civil servants whose positions were eliminated by the State modernization, so that they would be reinserted in the labor market. The legal structure of the Second State Reform was supplemented by Executive Order 558/96 the goals of which included the attainment of higher management efficiency, effectiveness and transparency. It established the need to review the personnel promotion systems and, to this end, it was necessary to create - within the presidential chief of staff's office - a Unit essentially devoted to complete the State reform process and elaborate a State Modernization Program for the second phase. As a result, the State Reform and Modernization Unit (URME) was created under such office. Its main functions were: 1) to design the Reform Program and the State Modernization Program; 2) to coordinate, follow up and control the actions relating to the State Reform and modernization in all Ministries, Secretariats in the President's office and centralized or decentralized Federal agencies; 3) to coordinate, follow up and oversee Institutional Strengthening Programs under progress or to be implemented, regardless of their financing modality, to ensure that they abide by the reform program, 4) to collect information considered necessary in order to comply with their functions, and to be compulsorily provided by Federal agencies, whether centralized or decentralized; 5) to inform, every 30 days, the Federal Executive Branch through the Presidential Chief of Staff (Cabinet Chief) on the progress of and deviations from the reform program; 6) to collaborate with the Provinces in their Reform and Modernization processes, by coordinating actions of the provincial agencies and the National Executive Branch bodies.

Executive Order 558/96 set forth that government organizations were obliged to submit to URME their projects for deregulation, transfer, merger, modernization and/or institutional strengthening. However, reacting to the lack of compliance with Executive Order 558/96, the Executive issued Executive Order 660/96 whereby it defined the makeup of the Federal government from the top down to the level of Under-secretariats. It also set forth the objectives and competencies for each government unit explaining what transfers, mergers and elimination's had to be undertaken in order to conduct the administrative reorganization. Also that same year, Executive Order 928/96 was issued establishing the responsibilities of several decentralized agencies in the design of a Strategic Plan and a Transformation Plan ${ }^{10}$. As provided for in Executive Order 558/96, URME - together with the Labor Ministry, the Civil Service Secretariat and the Ministry of Economy - was to review the Basic Legal System for the Civil Service, the bylaws and special personnel promotion systems as well as regulatory standards affecting labor productivity.

The results of the above-mentioned executive orders were as follows: 1) the term set by Executive Order 558/96 was insufficient to design the reengineering, modernization and institutional strengthening process necessary to undertake the

10 Each plan had to be submitted to URME with a redefinition of the agency's mission within the new role of the state parameters, citizen-oriented management, indicators to measure performance and results, human resource policies, remuneration levels with explicit productivity criteria, etc. 
reform; 2) Executive Order 660/96 did not reduce the number of Secretariats and decentralized agencies, it rather consolidated them; 3) the final liquidation of remaining agencies or bodies in the public sector was postponed through Administrative Decision 639/98, extending the deadline to December 31, $1997^{11}$.

The second State Reform has been analyzed [Bozzo et alii, 1996, 1997] based on five under performing aspects on which reforms should focus, namely 1) functions overlapping in a strict sense (generally with the President's office), 2) insufficient definition of competency limits (by subject, territory, etc.), 3 ) internal under performance (excessive or inadequate regulations), 4) policyregulation conflict, 5) transferable functions (those that can be decentralized or privatized). According to the above-mentioned analysis, the areas that most respected restrictions under Executive Order 660/96 were the Ministries of Justice, Defense, Education, Health and Labor - all of them State "functions not to be delegated" - which implied that the adjustment was more stringent in those areas. Although the objective of the Second Reform had to do with the consolidation of the state establishment as a "second-floor" structure, domestic security and direct social services - social security and subsidies - functions have been left in the Federal government area presumably with a political justification: 1) domestic security represents the power of repression and 2) social security and subsidies involve a large scale flow of economic-financial resources potentially useful to attract political clientele (grants and subsidies).

Although the objectives established to promote the State Reform refer to introducing structural changes, strengthening functions that cannot be delegated and eliminating those functions that can be better performed by private interests, "the redesign focused on aspects related to cutting spending and solving the fiscal deficit, rather than on a reorganization aimed at achieving more efficiency and transparency in State Management" [Bozzo et alii, 1997: 19]. The reform's fiscal result - although it had a relative economic meaning - appears as the only real achievement in the process. According to the empirical definitions given by the experts, the functional analysis of the State apparatus configuration leads them to conclude that "pre-existing under performance prior to the Reform persists in more than $80 \%$ " [Bozzo et alii, 1997: 20], particularly in the areas related to regulatory functions. External under performance of the federal administration (ministries, secretariats, undersecretaries and other agencies) was subjected to political compromises, and transferable functions barely suffered any changes. At most, there have been only a few innovation, adapting and modernization processes in the public administration revealed in some isolated experiences [Schweinheim, 1998; Ciai et alii, 1998], but, in general, the Second Reform failed since it was ruled by two simultaneous rationales: a logic of accumulation to reduce the fiscal deficit and attract the confidence of investors and creditors, and a logic of legitimacy, in the face of the inability to arise positive expectations and the loss of popularity during the second Menem's term in office [García Delgado, 1996].

11 These are remaining agencies from the privatized state-owned companies (telephones, railroads, etc.). 
A feature common to both the reforms undertaken is that they focus on the creation of institutions, rules and values guiding the actions of individuals and organizations, and responding to a similar design: many of the innovations are supported by legal standards providing the typical bureaucratic formality; they have coordinating or enforcement agencies with specific powers, similar management processes, etc. From the Weberian perspective, the adoption of this type of formal structures is successful in the modern world given their high capability to manage the dimensions of activities' coordination and control [Meyer and Rowan, 1991: 43]. In this sense, the adoption of more modern systems and new technologies would be the result of increased efficiency they would convey; and the fact that certain models tend to be adopted in a specific area would show their superiority over other models. However, following Meyer and Rowan [1991], Weber can be interpreted differently: certain structures are adopted not so much because of the efficiency they render but the legitimacy they provide [idem: 43-44]. Many formal elements of the structures are firmly embedded and reflect common interpretations of social reality. By acting as manifestations of institutional rules ${ }^{12}$, they operate as highly rationalized myths that legitimize organizations [idem: 44].

\section{8: State collective bargaining by the end of the Menem administration}

To confront or to subordinate: that was the question - resulting from the reallocation of resources and incentives - for State unions during the first phase of the public sector reforms between 1989 and 1995 [Orlansky, 2000]. Although the unions can be freely organized, there have been two main public employees unions - besides the teachers'. The Union of National Civil Servants (UPCN) has exercised corporative influence over recruitment operations, re-categorization and promotion, according to SINAPA provisions, aside from the fact that this union's leaders benefited by occupying executive positions in public agencies. On the other side of the spectrum, there was the Association of State Workers (ATE), which was alienated from any participation in SINAPA's promotion system decisions.

Over the last years of the Menem administration, both these unions exacerbated their differences. On the one hand, UPCN - guided by a business-like logic, especially in the management of the State workers Welfare Organization (which serves other workers as well), today has 60,000 full members totaling 230,000 with their families. It has developed a number of benefits for: full union members: 1) free school materials, 2) an additional $25 \%$ discount on medicines above that already provided by the Welfare Organization, 3 ) tourist packages with discounts higher than those provided by the Welfare Organization; members of the Welfare Organization alone: 1) upgrading of hospitals and clinics; 2) extension of the pharmacy network, 3) tourism plans; for the Federal government personnel, in

12 Not only the existence of the typical ministries and agencies of Economy, Education, etc. and accounting systems for payroll, etc. are examples of institutional rules. What is paradoxical is that innovation practices (non Weberian) proposed by the New Public Management are also institutional rules. 
general: 1) involvement in the drafting and implementation of the Collective Wage Bargaining and the Master Act, 2) renegotiations of Sector Agreements, 3) support to the development and institutionalization of mutual welfare organizations created by the workers of the various agencies to implement outsourcing methodologies. On the other hand, ATE is characterized by a tradition of demonstrations and of being "the opposition". Its members are more motivated in active participation in meetings and information events and less interested in belonging to a labor union concerned in attracting new members through selective incentives ${ }^{13}$ (as is the case of UPCN) ${ }^{14}$. ATE was more affected in terms of elimination of jobs, dismissals, suspensions and, in general, government policies. Although the institutional background of UPCN was not that strong in entrepreneurial management, they have raised the need to create a new role for the union, trying to organize it as an "Intermediary Management Body", i.e. an "... organization with the means necessary to mediate in accompanying, monitoring and training in undertakings..." for self-employment... "with the basic goal of triggering a dynamic process for the creation of new enterprises through the recruitment of personnel with a potential entrepreneurial profile"... "Generating effective employment, labor training and professional education programs, covering from intermediation between labor supply and demand to the support to creating new jobs or self-employment opportunities or, otherwise, social support" [Villaroel, 1999: 261-262].

The special feature of Menem's last period was - albeit late - in 1998 the phase of negotiations for the enforcement of the First Collective Wage Bargaining Agreement for the public sector. This would govern the working conditions for the Federal Civil Service (central government administration and decentralized agencies) totaling about 50,000 employees. The Agreement was officially approved on January 29, 1999 through Executive Order 66/99. In actual fact, already in 1987, Argentina had ratified the ILO Agreement 151, which guarantees the protection of the right to belong to a union and establishes the procedures to determine employment conditions in the civil service. However, during the first and rapid phase of State Reform in the Menem administration, the issue was totally ignored until 1991 when Congressman Adbala introduced in the House of Representatives a bill passed on December 16, 1992 under Act 24185. Such act set forth the provisions that would govern the negotiations between the Federal government (APN, Administración Pública National) and its employees: 1) it appoints the Labor Ministry as the agency responsible for determining the number of voluntary members recognized to each union, which will be reflected in the number of representatives in the committees; 2 ) it determines the subjects to be negotiated

13 The incentive must be "selective ", so that those who have not joined the organization that defends the interest of the group or in some way contribute to meet those interests are treated differently from those who do join it [Olson, 1992: 60].

14 It is important to highlight that, unlike what happens in some private sector activities, where all employees contribute to sustain the unions, in the case of state employee unions, contributions only come from its members. For state unions, the percentages vary between $3 \%$ and $2 \%$ depending on whether they are members of UPCN or ATE, respectively. 
including labor matters comprising employment relationship, as regards both salary content and other labor conditions, etc.; 3) it establishes that the organizational structure of the Federal government, the State powers and the principle of suitability and knowledge for a position and promotion in the civil service career are not issues to be negotiated; 4) it details the possibility of appointing a mediator in case an agreement is not reached. The Executive Branch, through Executive Order 447/93 regulated Act 24185, establishing that only signatory unions of the Agreement would be beneficiaries of the union contribution. Short time before, also in 1993, the Congress had ratified the ILO Agreement No.154 on the promotion of collective bargaining in general.

Between 1993 and 1997, the Collective Agreement for the State personnel was not included as a priority in the government agenda, which was filled by other more urgent and relevant issues, such as the impact of the "Tequila effect", and the Reform of the National Constitution in 1994, which would now allow the reelection of the president in 1995. Also, the confrontations between UPCN and ATE did not allow working together towards introducing the Collective Agreement in the political agenda. For UPCN, the delay was also caused by other factors "related to the closer opposition that this alternative brought about in some civil service career sectors and political officials" [Auton, 1999: 242]...

In 1997, the Executive Branch introduced a bill in the House of Representatives aimed at passing a Master Act for National Public Employment Regulation, the main objective of which was to replace the Basic Legal System of the Civil Service ${ }^{15}$ as well as to consolidate into one sole regulation many legal provisions on civil service employment. This bill was strongly rejected by the unions as it "provided for a rigid regime which granted excessive discretional powers to the administrative authority". The House Labor Legislation Committee, with the collaboration of legal representatives from UPCN and ATE submitted to the vote an agreed bill which was passed by the House on November 1998 and, almost a year later, on September 15, 1999, was unanimously approved both by the House and the Senate to became Act 25164. Such bill received strong criticism from some State sectors because, although it was agreed by the unions, it had not be agreed by the state in its capacity as employer, since the latter had not been convened to present possible changes. There was even the possibility for the Executive Branch to veto the bill, but the union pressures made the Executive decline its intention. The union's interest was essentially to set up the Permanent Training Fund an issue, which neither the Act nor the Agreement has developed at length and has created endless expectations ${ }^{16}$. However, it was never implemented. President Menem issued Executive Order 1596 for its regulation on December 9, 1999, his last day in office. But a few days after President De la Rúa took office, on January 18, 2000,

15 It includes a set of rules for Federal government personnel, many of which were established during the military rule between 1976 and 1983. Its reform was provided for in the Second State Reform of 1996, Executive Order 558/96.

16 According to ATE informants, this is a Fund that would command an 86-million dollar budget per year for spending on civil servants training. Its implementation would be decentralized by agencies and would be managed mostly by UPCN. 
through Executive Order 69/00, he abolished Executive Order 1596/99 whereby the regulation of the Annex to the Master Act for Public Employment Regulation had been approved but not yet published in the Official Gazette.

But the discussion and process of approval of the Master Act in the House was the triggering event that imposed an agreement on the contents of the Collective Agreement a month after it had been favorably voted (on December 15, 1998). Although the ATE rejected it and did not sign the bill, it was officially approved by the signature of the UPCN and the government. ATE proposed longer leaves of absence, a much higher remuneration and did not mention the new labor relations such as the creations of social welfare institutions, cooperatives, outsourcing, etc. Also, the relationship between ATE and the UPCN was a difficult one from the very beginning mainly due to the ideological differences between both unions. Formally, the conflict came from their inability to come to terms on the number of voluntary members for each. The Labor Ministry had to intervene and determined that $72.30 \%$ of the members belonged to UPCN and $27.69 \%$ to ATE. This proposition did not please ATE.

The Agreement was published in the Official Gazette and, immediately afterwards, ATE filed an action to suspend the enforcement of the Agreement and obtained a favorable decision. In turn, the State, through the Labor Ministry filed a recourse reverting the court decision.

The General Labor Collective Agreement signed by the State as Employer and Union Sectors, effective between January 1, 1999 and December 31, 2000, set forth the conditions for admission to the National Civil Service, specified the terms and conditions in relation to public employment, featured the most important factors for personnel career, defined performance as the essential component in personnel assessment, established a remuneration's system, the disciplinary regime and the environmental and working conditions of the Federal Civil Service.

The Agreement introduces flexibility in the function (multi-functionality) and mobility in terms of positions and geographic location ${ }^{17}$, with a view to increasing "the productivity of the public sector and modernizing its management", two new concepts for state employees. Another relevant change is the determination of the working time ${ }^{18}$, which cannot exceed 180 hours or be under 120 hours, thus making the workers' time "flexible".

Other innovations relate to women, the most important being the 10-day extension of maternity leave, i.e. from 90 to 100 days. Also, the Agreement dedicates a whole chapter to the right to equal opportunities and treatment. When making reference to the "Promotion of Working Women", it increased the resting time for breast-feeding one more hour. A worker is granted 100 pesos (100 dollars) reimbursement for payment of day care. A male parent is also allowed to take a five business day leave for the birth of his child.

17 Functional flexibility refers to the internal organization. It implies less fragmenting, fewer divisions of labor and greater internal mobility [OECD, 1996: 29].

18 The working hours flexibility refers to the workday weekday duration, to the year organization, flextime, elimination of restrictions to night work and obligatory off-time [OECD, 1996: 29]. 
Other "victories" obtained by UPCN in the negotiation are, for instance, the payment of overtime at $100 \%$ value - compared to the past overtime hours paid at $50 \%$ rate -; the creation of an oversight and regulation committee for ensuring proper environmental and working conditions; the break time for snacks, which had not be regulated before; the number of union representatives and the number of hours of credit for union activity.

We could state that, beyond the above mentioned changes, the Agreement is an innovation in itself, since it was the first time the State had to negotiate with its workers, to guarantee certain rights and to fulfill certain obligations, and to accept in virtually all labor aspects, a set of guidelines imposed by the Agreement. In general terms, aside from proposing the flexibilization of working hours and a greater mobility in civil service, the Agreement establishes that the salary framework provided for under Act 24185 is, however, conditioned to budgetary acceptance. It maintains the principle and right to stability as guaranteed by the National Constitution and it covers workers who have a one year signority and may prove a psychophysical fitness and performance certificate.

Over the last decade, the public sector in Argentina fruitlessly undertook two challenges: to reduce the budgetary deficit and, in general, public spending, and the policies of state reduction and modernization. Retrenchment of public employment was only and exclusively due to the privatization of State owned companies and the reduction of the official banking sector. A strong withdrawal of personnel prior and, in some cases, after its transfer featured the process of privatization. Telephone companies, airlines, steel industry, electricity, railways, oil, sewing, etc. as well as the banking sector applied voluntary resignation plans with convenient compensations. To make the difficult tasks of management of dismissals easier, international agencies and multilateral banks granted huge credits. Labor conflicts - mostly in the public sector $(65 \%)$ - decreased insofar labor organizations of privatized sector had rather turned into business entities and ended with their former role of noisy contentional unions. In fact, their project consisted of getting involved as private economic agents in the provision of healthcare and retirement business, also an ex-state-managed area of public services. The implementation of the Stock Ownership Participation Program also contributes to favor a time of social peace, turning employees into holders of at least $10 \%$ of the company's shares.

The transformations in the production systems and their resulting impact on labor relations have also had an effect on the federal civil service. The Collective Agreement has been instituted within the Federal government and its main contribution has been the introduction of working flexibilization aimed at improving organization effectiveness and ability to cope with environmental variations. This implies abandoning "universalist, regulatory and centralized" methods and a shift to a result-oriented activity coupled with human and financial resources management methods based on a greater decentralization of responsibilities and the adaptation to current environment [OECD, 1996: 122]. 
The superseding of the Weberian model is widely shared with many current experiences. In the case of Sweden, an attempt has been made to develop a remuneration system based on concepts such as performance and personal development, setting aside the salary unification system. This completely new measure has presented problems for its implementation as managers do not have a formal or quantified system to base their decisions on, making them totally subjective and creating resistance. Problems have been detected related to organization and cultural factors rather than to public sector managers resistance to change [Wise, 1999]. In Norway, the proposals of the New Public Management suffer from problems of adaptation to the local context and, in particular, they apply to management innovations relating to planning, effectiveness, efficiency, quality, etc. It has greater acceptance among those who are more related to economic aspects and with change results, rather than among those more involved with procedures or legal matters [Cristensen, Laegreid, 1998]. In Argentina, the changes introduced in labor relations within the public sector were controversial. The role played by State personnel unions is very important. On the one hand, changes were accepted and even encouraged by UPCN - a pro-Menemist union - with great capacity to reorganize in the face of reform-generated opportunities. But, on the other hand, changes were rejected by ATE - a confrontational union struggling to maintain or accentuate the conditions prior to the reforms. However, public employment in the Federal government continues to maintain working conditions comparatively more advantageous than in the private sector. Below is a detail of some favorable differences.

1) Working hours flexibility in the public sector does not affect the remuneration level, since stability also covers remuneration. In the case of the private sector, fewer working hours mean a reduction in salaries. Even worse, the concept of stability is unknown by private sector employees mainly with the increase use of fixed term contracts.

2) The night shift for State workers has one hour less.

3) Leaves of absence for vacations or special leaves (marriage, birth, study or death of a relative) are more beneficial in the public sector than in the private sector, averaging between 5 and 10 days more, depending on the case.

4) Working conditions for women (maternity leaves, breast-feeding and child care) are comparatively better in the public sector.

Even with the changes introduced, both working conditions and salary averages for civil servants continue to be much more beneficial than those legislated for the private sector and infinitely better than the latter's actual situation in 1999.

Starting in 2000, concurrently with the new De la Rúa administration, a new phase has started. But this will be the subject of a different chapter.

\section{BIBLIOGRAPHY}

ACKerman M. [1998], Trabajadores del Estado en Iberoamerica, Buenos Aires, Ciudad Argentina: 11-38.

Auton O. [1999], « Estabilidad, movilidad, polivalencia funcional. Las controversias de los nuevos desafíos laborales », in N. Rial (ed.), Estado argentino. Transformación de las relaciones laborales, Buenos Aires, Fundación Unión: 221-247. 
Bekke H.A.G, Perry J.L., Toonen T.A.J. (eds) [1996], Civil Service Systems in Comparative Perspective, Bloomington, Indiana, Indiana University Press, 346 p.

BonANOTTE C. [1996], « Las luchas laborales del personal del Estado durante la etapa inicial del Plan de Convertibilidad », Paper presented at the 3th Congreso Nacional de Estudios del Trabajo, ASET, Buenos Aires, September 3-6, 25 p.

Bozzo C., López B., Rubins R., ZapaTa A. [1997], « La segunda reforma del Estado: balance », Cuaderno CEPAS, No. 5, Buenos Aires, CEPAS, 59 p.

Bozzo M.C., López B.H., Zapata A. [1996], « Los procesos de Reforma del Estado. La Segunda Etapa y su agenda », Aportes, 6 (3): 89-103.

Bresser Pereira L.C. [1998], " La reforma del Estado en los años noventa », Desarrollo Económico, 150 (38): 517-550.

CEUNM, Centro de Estudios Unión para la Nueva Mayoría, Boletines Informativos, Buenos Aires, No.39, 1990; No. 53, 1991; No. 54 y No. 64, 1992; No. 68 y No. 75, 1993; No. 77, 1994.

Christensen T., Laegreid P. [1998], « New Public Management. Design, Resistance or Transformation? », Paper presented at the Annual Meeting of the American Political Science Association, Boston, September 3-6, 32 p.

Ciai A., Darmohraj A., Schweinheim G. [1998], « De la modernización a la Innovación en el sector público ", Nueva Época, Revista de Investigaciones del INAP, 0 (0): 49-82.

Di Maggio P., Powell W. [1991], « The Iron Cage Revisited: Institutional Isomorphism and Collective Rationality in Organizational Fields », in P. Di Maggio, W. Powell (eds), The New Institutionalism in Organizational Analysis, Chicago and London, University of Chicago Press: 63-82.

Falcon R. [1993], «Políticas Neoliberales y Respuestas Sindicales (1989-1992) », in Omar Moreno (ed.), Desafíos Para el Sindicalismo en la Argentina, Buenos Aires, Legasa: 93-106.

Figari C. [1995], "La problemática de las calificaciones y la flexibilidad laboral. El caso de una central eléctrica privatizada ", Presented at the II Congreso Nacional de Ciencia Política, Mendoza, Argentina, 35 p.

Fraga R. [1991], La cuestión sindical, Buenos Aires. Centro de Estudios Unión para la Nueva Mayoría.

García Delgado D. [1996], " La reforma del Estado en la Argentina », Paper presented at I Congreso Interamericano del CLAD, CLAD - http: www.clad.org.ve-siareweb. Congresos.

Gerchunoff P., Cánovas G. [1995]: "Privatizaciones en un contexto de emergencia económica », Desarrollo económico, 136 (34): 483-512.

Grindle M., Thomas J. [1991], Public Choices and Policy Change. The Political of Reform in Developing Countries, Baltimore, The Johns Hopkins University Press, 233 p.

Grindle M. [1996], Challenging the State, Cambridge, Cambridge University Press, 243 p.

INAP [1997], Reseña del proceso de Reforma del Estado en la Argentina. 1989-1996, Buenos Aires, $60 \mathrm{p}$.

INFORME A.G. [1994], «Transferencia de Servicios Educativos », APORTES, 2 (1): 32-40.

Meyer J., Rowan B. [1991], «Institutionalized Organizations: Formal Structure as Myth and Ceremony ", in P. Di Maggio, W. Powell (eds), The New Institutionalism in Organizational Analysis, Chicago and London, University of Chicago Press: 41-62.

MuRiLLO V. [1997], " La adaptación del sindicalismo argentino a las reformas de mercado en la primera presidencia de Menem », Desarrollo económico, 147 (37): 419-446.

OECD [1996], Ministerial Symposium on the Future of Public Services, Paris.

Olson M. [1992], "Una teoría de los grupos y las organizaciones ", in La lógica de la Acción Colectiva, México, Limusa: 15-61.

Orlansky D. [1989], «Empleo público y condiciones de trabajo », Desarrollo económico, 113 (29): 63-86.

OrLansky D. [1991], «El nuevo orden administrativo. Reforma del Estado y empleo público en Argentina 1989-1991 ", in Reestructuración y regulación del mercado de trabajo en América Latina, Instituto Internacional de Estudios Laborales, ILO, Geneve, Serie de Investigaciones, No.98: 335-350.

Orlansky D. [1994], "Crisis y Transformación del Estado en la Argentina », CICLOS, 7 (4): 3-28. 
Orlansky D. [2000], « Implementing State Argentine State Reform. Union Cooperation or Conflict? ", in S.S. Nagel (ed), Handbook of Global Economic Policy, New York, Marcel Dekker, Inc.: 495-510.

OsaKi M. [1997], « Las relaciones de trabajo en la administración pública », Revista Internacional del Trabajo, 3 (106): 303-328; 4 (106): 471-490.

Ostrom V. [1982], « New Conceptual Developments and Opportunities for Reform », in G.E. Caiden, H. Siedentopf (eds), Strategies for Administrative Reform, Lexington, Lexington Books, R.C. Heath \& Co, Massachusetts: 25-39.

Oszlak O. [1999], De menor a mejor: el desafío de la "segunda » reforma del Estado, mimeo, 19 p.

Palomino H. [1988], « Hacia una nueva relación entre sindicatos y Estado en Argentina », Paper presented at XVII Congreso Latinamericano de Sociología, Montevideo, Uruguay, CISEA, $36 \mathrm{p}$.

RinNE J. [1996], « Civil Servant Unions and Administrative Reform Strategic: Brazil and Argentina under Collor and Menem », Paper presented at I Inter-American Conference of CLAD on Administrative Reform in Latin America, Rio de Janeiro, Brasil, November 6-9: 315-334.

Rodriguez Mancini J. [1990], "La negociación colectiva en el sector público », in La negociación colectiva, Buenos Aires, Astrea: 133-147.

Rofman A. [1994], «Privatización/Reestructuración. El caso Somisa », APORTES, 2 (1): 100-124.

SARAVIA E. [1997], Seminario sobre la situación laboral del personal de la administración pública en los países de América Latina, CLAD-PNUD, Santo Domingo, Abril 24-25, Serie Documentos Reuniones Internacionales No.1, http. www.clad.org-siareweb-Congresos.

SCHWEINHEIM G. [1998], «Innovación en administración, gestión y políticas públicas: ¿es idéntico a modernización? ", Nueva Época, Revista de investigaciones del INAP, 0 (0): 31-47.

Villarroel A. [1999], « La reforma del estado. Los desafíos pendientes », in N. Rial (ed), Estado argentino. Transformación de las relaciones laborales, Buenos Aires, Fundación Unión: 249-267.

Williamson J. [1993], « Democracy and the "Washington Consensus", World Development, Special Issue ", Lawrence Whitehead (ed.), Economic Liberalization and Democratization: Explorations of the Linkages: 1329-1336.

Wise L.R. [1999], «The Use of Innovative Practices in the Public and Private Sectors: the Role of Organizational and Individual Factors », Public Productivity \& Management Review, 2 (23): 150-168. 